\section{Successful Desensitization to Daratumumab After a Severe Life-threatening Reaction in a Patient With Refractory Multiple Myeloma}

Carrón-Herrero $\mathrm{A}^{1 *}$, Solano-Solares $\mathrm{E}^{1 *}$, Geraldine Rita $\mathrm{C}^{2}$, Rodríguez-Martín $\mathrm{E}^{2}$, Ruedas A $^{3}$, Barbolla ${ }^{3}$, Berges-Gimeno MP ${ }^{1,4}$ ${ }^{I}$ Allergology Department, Hospital Universitario Ramón y Cajal, IRYCIS, Madrid, Spain

${ }_{2}^{2}$ Immunology Department Hospital Universitario Ramón y Cajal, IRYCIS, Madrid, Spain

${ }^{3}$ Internal Medicine Department, Hospital Universitario Ramón y Cajal, IRYCIS, Madrid, Spain

${ }^{4}$ Spanish Thematic Network and Co-operative Research Centres, ARADyAL, Spain

*Both authors contributed equally and should be considered first authors.

J Investig Allergol Clin Immunol 2021; Vol. 31(6): 511-513 doi: $10.18176 /$ jiaci.0678

Key words: Daratumumab. Anaphylaxis. Desensitization. Multiple myeloma. Monoclonal antibody.

Palabras clave: Daratumumab. Anafilaxia. Desensibilización. Mieloma múltiple. Anticuerpo monoclonal.

Multiple myeloma (MM) is a clonal proliferation of malignant bone marrow plasma cells with high and uniform expression of CD38 [1]. Survival has improved with autologous stem cell transplantation, proteasome inhibitors (bortezomib and carfilzomib), and immunomodulatory drugs (lenalidomide, thalidomide, and pomalidomide). Nevertheless, most patients die of refractory disease despite the use of the abovementioned first-line therapies. Humanized monoclonal antibodies represent a significant addition or even the only therapeutic option for the treatment of refractory MM. Daratumumab is a novel $\mathrm{IgG} 1 \kappa$ human monoclonal antibody that binds to CD38 and induces apoptosis [1]. Around 38.8\% of patients treated with daratumumab develop infusion-related reactions (IRRs) after the first or second dose. They usually present with grade 1 or 2 IRRs, which manifest as rhinitis, cough, dyspnea, bronchospasm, chills, and nausea. Grade 3-4 IRRs are rare $(3.8 \%)$ [1].

A 66-year-old woman with a history of refractory MM started treatment with daratumumab (final dose, $896 \mathrm{mg}$ ) owing to disease progression. This included intravenous premedication with $5 \mathrm{mg}$ dexchlorpheniramine, $1000 \mathrm{mg}$ paracetamol, and $20 \mathrm{mg}$ dexamethasone administered 60 minutes prior to the infusion. Within 30 minutes of initiating daratumumab, the patient developed flushing, oropharyngeal pruritus, bronchospasm, and poor respiratory mechanics. The vital signs were as follows: oxygen saturation, $85 \%$; blood pressure, $80 / 40 \mathrm{mmHg}$; pulse, 60 bpm; and temperature, $36.5^{\circ} \mathrm{C}$.

The infusion was stopped, and intravenous methylprednisolone $(60 \mathrm{mg})$, hydrocortisone $(200 \mathrm{mg})$, dexchlorpheniramine ( $5 \mathrm{mg}$ ), and intramuscular epinephrine $(0.5 \mathrm{mg})$ were administered. Nevertheless, the patient's symptoms progressed, with right oculocephalic deviation, lack of glabellar and menace reflexes, and hypercapnic respiratory acidosis. Therefore, she was admitted to the intensive care unit, where invasive mechanical ventilation and a norepinephrine perfusion were started. The patient's condition stabilized, and she was successfully extubated after 2 days without neurological sequelae. No tryptase levels were measured. A grade 4 IRR [2] was diagnosed, and the patient was referred to our allergy department. Skin tests with daratumumab (skin prick test at concentrations of $20 \mathrm{mg} / \mathrm{mL}, 2 \mathrm{mg} / \mathrm{mL}$, and $0.2 \mathrm{mg} / \mathrm{mL}$ and an intradermal test at concentrations of $2 \mathrm{mg} / \mathrm{mL}$ and $0.2 \mathrm{mg} / \mathrm{mL}$ ) performed 3 weeks after the reaction yielded negative results [3]. Baseline tryptase was $3.41 \mathrm{ng} / \mathrm{mL}$ (normal, $<11.5 \mathrm{ng} / \mathrm{mL}$ ). A basophil activation test (BAT) to daratumumab was performed at different concentrations $(0.5 \mathrm{mg} / \mathrm{mL}, 1 \mathrm{mg} / \mathrm{mL}$, and $2 \mathrm{mg} / \mathrm{mL})$ using the 2 most common markers of activation/degranulation (CD203c and CD63) [4], with negative results for all the concentrations tested. The referring physicians confirmed that daratumumab was the best therapeutic option owing to disease progression and failure of first-line therapy. We assessed the risks for management, and the informed consent was signed. Based on risk stratification for the severe reaction, a 4-bag, 14-step rapid drug desensitization (RDD) protocol was administered [5]. Additional premedication was with montelukast and aspirin, and no breakthrough reactions were recorded (Table). IL-6 levels were measured using high-sensitivity single-molecule array (Simoa) technology [6], which reduces IL-6 levels after desensitization (baseline, $21.85 \mathrm{pg} / \mathrm{mL}$; after desensitization, $<2 \mathrm{pg} / \mathrm{mL}$ ). To date, the patient has tolerated 15 cycles without incident. Disease control is excellent.

Hypersensitivity reactions to monoclonal antibodies include infusion-related reactions, cytokine-release reactions (CRRs), type 1 reactions (IgE/non-IgE), type 3 reactions (immune complexes), and delayed type 4 reactions [3]. IRRs and CRRs to monoclonal antibodies can occur at the first infusion. In most cases, the difference between IRRs and CRRs is the self-limiting nature of IRRs on repeat exposure and the response to premedication [5]. Although the patient received premedication according to the summary of product characteristics of daratumumab, she developed a severe lifethreatening reaction. No IgE-mediated hypersensitivity reactions to daratumumab have been reported to date. Polysorbate 20 and mannitol are excipients of daratumumab. Cases of anaphylaxis due to sensitization to mannitol and polysorbate (mainly polysorbate 80 ) have been reported $[7,8]$. Since no IgE-mediated mechanism was demonstrated in the present case following skin tests and BAT, and given that the patient developed a severe life-threatening reaction despite receiving adequate premedication following the summary of product characteristics, we considered CRRs to be a possible underlying mechanism of the severe reaction and thought that the patient could benefit from an RDD protocol for administration of daratumumab [3]. Given the negative skin test results with daratumumab, further studies with mannitol and polysorbate 20 were not performed.

Desensitization by expert allergists is a powerful tool that is both safe and effective for maintaining treatment in patients 
Table. Ramón y Cajal University Hospital Standard Rapid Desensitization Protocol Adapted for a Total Dose of 896 mg of Daratumumab Diluted in a Volume of $250 \mathrm{~mL}$ of Saline Solution $0.9 \%$ a

\begin{tabular}{|c|c|c|c|c|c|c|c|}
\hline \multicolumn{2}{|c|}{ Total Dose } & $896 \mathrm{mg}$ & \multicolumn{2}{|c|}{$\begin{array}{c}\text { Solution concentration, } \\
\mathrm{mg} / \mathrm{mL}\end{array}$} & \multicolumn{2}{|c|}{$\begin{array}{l}\text { Total dose in each solution, } \\
\text { mg }\end{array}$} & Drug \\
\hline \multicolumn{2}{|c|}{ Solution A } & $250 \mathrm{~mL}$ & \multicolumn{2}{|c|}{0.0072} & \multicolumn{2}{|c|}{1.8} & Daratumumab \\
\hline \multicolumn{2}{|c|}{ Solution B } & $250 \mathrm{~mL}$ & \multicolumn{2}{|c|}{0.072} & \multicolumn{2}{|c|}{18} & Daratumumab \\
\hline \multicolumn{2}{|c|}{ Solution C } & $250 \mathrm{~mL}$ & \multicolumn{2}{|c|}{0.716} & \multicolumn{2}{|c|}{179} & Daratumumab \\
\hline \multicolumn{2}{|c|}{ Solution D } & $250 \mathrm{~mL}$ & \multicolumn{2}{|c|}{3.024} & \multicolumn{2}{|c|}{756} & Daratumumab \\
\hline Step & Solution & $\begin{array}{c}\text { Volume } \\
\text { administered, } \mathrm{mL}\end{array}$ & $\begin{array}{l}\text { Rate, } \\
\mathrm{mL} / \mathrm{h}\end{array}$ & $\begin{array}{l}\text { Time, } \\
\min \end{array}$ & $\begin{array}{c}\text { Dose } \\
\text { administered, mg }\end{array}$ & $\begin{array}{l}\text { Fold increase } \\
\text { per step }\end{array}$ & $\begin{array}{l}\text { Approximate cumulative } \\
\text { dose infused, mg }\end{array}$ \\
\hline 1 & A & 22 & 88 & 15 & 0.0 & NA & 0.0 \\
\hline 2 & A & 25 & 100 & 15 & 0.2 & NA & 0.2 \\
\hline 3 & A & 50 & 200 & 15 & 0.4 & $\times 2$ & 0.6 \\
\hline 4 & A & 100 & 400 & 15 & 0.7 & $\times 2$ & 1.3 \\
\hline 5 & B & 22 & 88 & 15 & 0.0 & NA & 1.3 \\
\hline 6 & $\mathrm{~B}$ & 25 & 100 & 15 & 1.8 & $\times 2.5$ & 3.1 \\
\hline 7 & B & 50 & 200 & 15 & 3.6 & $\times 2$ & 6.7 \\
\hline 8 & B & 100 & 400 & 15 & 7.2 & $\times 2$ & 13.9 \\
\hline 9 & $\mathrm{C}$ & 22 & 88 & 15 & 0.0 & NA & 13.9 \\
\hline 10 & $\mathrm{C}$ & 25 & 100 & 15 & 18 & $\times 2.5$ & 31.9 \\
\hline 11 & $\mathrm{C}$ & 50 & 200 & 15 & 36 & $\times 2$ & 67.9 \\
\hline 12 & $\mathrm{C}$ & 100 & 400 & 15 & 72 & $\times 2$ & 139.9 \\
\hline 13 & $\mathrm{D}$ & 22 & 88 & 15 & 0.0 & NA & 139.9 \\
\hline 14 & $\mathrm{D}$ & 250 & 125 & 120 & 756 & $\times 2.6$ & 896 \\
\hline
\end{tabular}

Abbreviation: NA, not applicable.

aTotal infusion time: 315 minutes ( 5.2 hours)

who react to monoclonal antibodies [3,9]. In the case of the CRR endotype/phenotype, a desensitization protocol could enable the drug to be reintroduced [3].

The molecular mechanisms of CRRs are not completely understood, and it is unclear whether mast cells play a key role in the underlying molecular mechanisms. T-cell activation and release of proinflammatory cytokines such as IL-6 and TNF- $\alpha$ play a major role. Isabwe et al [3] reported the cases of 8 patients who reacted during desensitization, with high IL-6 levels. Consequently, IL-6 and other proinflammatory cytokines may be responsible for the clinical picture of reacting patients who experienced CRRs and could be important biomarkers for identification of these symptoms. Sancho-Serra et al [10] noted that early and late IL- 6 and TNF- $\alpha$ production were lower in desensitized cells than in activated cells.

We believe that this is the first report of IL- 6 measurements in nonreacting patients before and after desensitization to monoclonal antibodies. Consequently, we do not know how IL-6 levels may vary.

The downregulation of IL-6 that we observed after desensitization could explain the absence of symptoms. As this is a single case report, further studies are needed to confirm our findings.
To our knowledge, we report the first successful desensitization following an RDD protocol in a patient with severe life-threatening CRR to daratumumab.

\section{Funding}

The authors declare that no funding was received for the present study.

\section{Conflicts of Interest}

Maria Pilar Berges Gimeno declares the following conflict of interest:

Grant from Instituto Carlos III Madrid, Spain.

Grant from Instituto Fundación Merck Salud, Spain.

The remaining authors declare that they have no conflicts of interest.

\section{References}

1. Al Hadidi S, Kamble R, Miller-Chism CM, Mims MP. Safety Analysis of Five Randomized Controlled Studies of Daratumumab in Patients with Multiple Myeloma. Clin Lymphoma Myeloma Leuk. 2020;20(9):e579-89. 
2. Cmelak AJ, Lordick F, Borner MM, Goldberg RM, Wasif Saif M. Management of Infusion Reactions in Clinical Trials and Beyond: The US and EU Perspectives. Oncology. 2009;23:1825.

3. Isabwe GAC, Carcia M, de Las Vecillas L, Lynch DM, Marquis K, Castells MC. Hypersensitivity reactions to therapeutic monoclonal antibodies: Phenotypes and endotypes. J Allergy Clin Immunol. 2018;142:159-70.

4. Thévenot J, Ferrier le Bouëdec MC, Buisson A, Bommelaer G, D'Incan M, Rouzaire P. Rapid Desensitization to Adalimumab Is Associated With Decreased Basophil Sensitivity. J Investig Allergol Clin Immunol. 2019;29(2):141-3.

5. Madrigal R, Bernal L, Berges MP, Carpio LV, Gehlhaar P, Alvarez E. A Large Single-Hospital Experience Using Drug Provocation Testing and Rapid Drug Desensitization in Hypersensitivity to Antineoplastic and Biological Agents. J Allergy Clin Immunol Pract. 2019;7:618-32.

6. Yeung D, Ciotti S, Purushothama S, Gharakhani E, Kuesters G, Schlain $B$, et al. Evaluation of highly sensitive immunoassay technologies for quantitative measurements of sub-pg/mL levels of cytokines in human serum. J Immunol Methods. 2016;437:53-63.

7. Hegde VL, Venkatesh YP. Anaphylaxis to excipient mannitol: evidence for an immunoglobulin E-mediated mechanism. Clin Exp Allergy. 2004;34:1602-9.

8. Badiu I, Geuna M, Heffler E, Rolla G. Hypersensitivity reaction to human papillomavirus vaccine due to polysorbate 80 . BMJ Case Rep. 2012 May 8;2012:bcr0220125797.

9. De Lira Quezada CE, Villarreal González RV, González Díaz SN, Acuña Ortega N. Protocol for Desensitization to Trastuzumab in a Patient With Anaphylaxis and Stage IV Breast Cancer: A Case Report. J Investig Allergol Clin Immunol. 2020;30(5):3767.

10. Sancho-Serra Mdel C, Simarro M, Castells M. Rapid IgE desensitization is antigen specific and impairs early and late mast cell responses targeting $\mathrm{F} c \varepsilon \mathrm{RI}$ internalization. Eur J Immunol. 2011;41(4):1004-13.

- Manuscript received September 22, 2020; accepted for publication February 4, 2021.

Maria Pilar Berges Gimeno

Carretera Colmenar Viejo, km 9,100

28034 Madrid

E-mail: berges.pilar@gmail.com 